\title{
ॠUSGS
}

science for a changing world

Prepared in cooperation with the Commonwealth of Massachusetts Massachusetts Geological Survey and Executive Office for Administration and Finance

\section{Surficial Geologic Map of the Norton-Manomet-Westport- Sconticut Neck 23-Quadrangle Area in Southeast Massachusetts}

Compiled by Byron D. Stone, Janet R. Stone, Mary L. DiGiacomo-Cohen, and Kevin A. Kincare

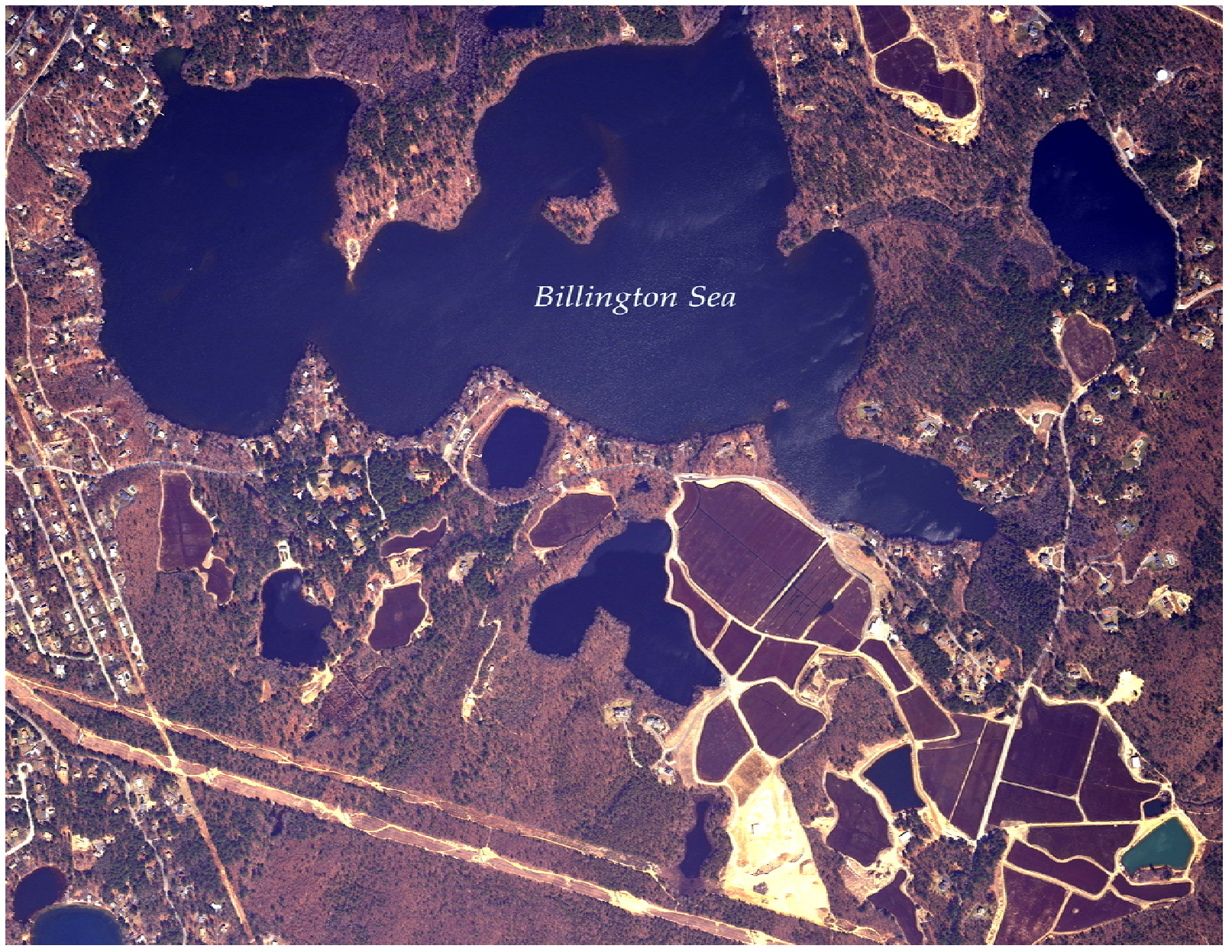

Open-File Report 2006-1260-F

U.S. Department of the Interior

U.S. Geological Survey 


\title{
U.S. Department of the Interior \\ KEN SALAZAR, Secretary
}

\author{
U.S. Geological Survey \\ Marcia K. McNutt, Director
}

U.S. Geological Survey, Reston, Virginia: 2011

For product and ordering information:

World Wide Web: http://www.usgs.gov/pubprod

Telephone: 1-888-ASK-USGS

For more information on the USGS—-the Federal source for science about the Earth, its natural and living resources, natural hazards, and the environment:

World Wide Web: http://www.usgs.gov

Telephone: 1-888-ASK-USGS

Suggested citation:

Stone, B.D., Stone, J.R., DiGiacomo-Cohen, M.L., and Kincare, K. A., comps., 2011, Surficial geologic map of the Norton-Manomet-Westport-Sconticut Neck 23-quadrangle area in southeast Massachusetts: U.S. Geological Survey Open-File Report 2006-1260-F, 21 sheets, scale 1:24,000, 22-p. text.

Any use of trade, product, or firm names is for descriptive purposes only and does not imply endorsement by the U.S. Government.

Although this report is in the public domain, permission must be secured from the individual copyright owners to reproduce any copyrighted material contained within this report.

Cover figure: Kettle depressions, cranberry bogs, and sand and gravel operations in Plymouth, Massachusetts. The Billington Sea is a large compound kettle. Older, smaller cranberry bogs occupy natural kettle depressions. Newer, larger cranberry bogs occupy kettle depressions and excavated sand and gravel deposits. 


\section{Contents}

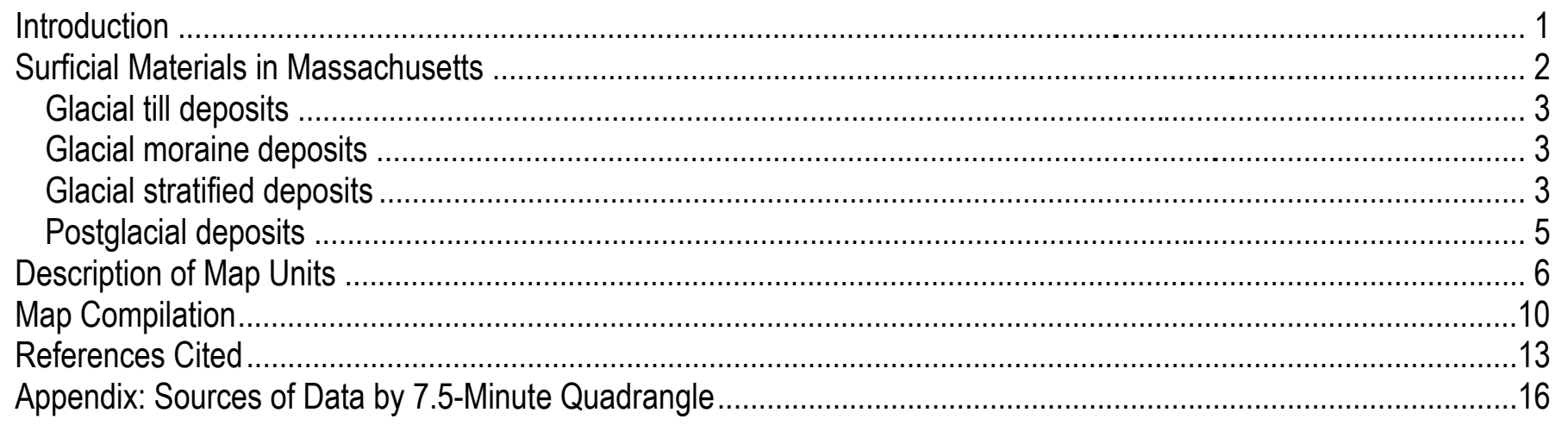

\section{Figures}

1. Map showing general distribution of glacial and postglacial deposits in Massachusetts and map area of this report

2. Block diagram illustrating the typical areal and vertical distribution of glacial and postglacial deposits overlying

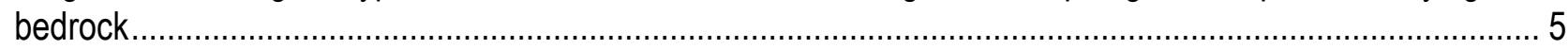

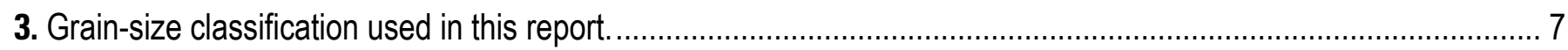

4. Index map showing 7.5-minute, 1:24,000-scale quadrangles in this compilation ............................................ 11

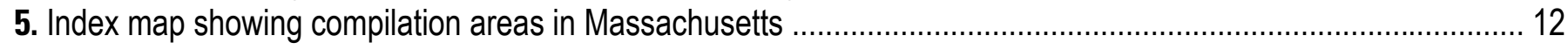




\section{Conversion Factors}

\begin{tabular}{|c|c|c|}
\hline Multiply & By & To obtain \\
\hline \multicolumn{3}{|c|}{ Length } \\
\hline inch (in.) & 2.54 & centimeter $(\mathrm{cm})$ \\
\hline inch (in.) & 25.4 & millimeter (mm) \\
\hline foot (ft) & 0.3048 & meter $(\mathrm{m})$ \\
\hline mile (mi) & 1.609 & kilometer (km) \\
\hline mile, nautical (nmi) & 1.852 & kilometer (km) \\
\hline yard (yd) & 0.9144 & meter (m) \\
\hline centimeter $(\mathrm{cm})$ & 0.3937 & inch (in.) \\
\hline millimeter (mm) & 0.03937 & inch (in.) \\
\hline meter (m) & 3.281 & foot $(\mathrm{ft})$ \\
\hline kilometer (km) & 0.6214 & mile (mi) \\
\hline kilometer (km) & 0.5400 & mile, nautical (nmi) \\
\hline meter (m) & 1.094 & yard (yd) \\
\hline \multicolumn{3}{|c|}{ Area } \\
\hline square mile $\left(\mathrm{mi}^{2}\right)$ & 2.590 & square kilometer $\left(\mathrm{km}^{2}\right)$ \\
\hline square kilometer $\left(\mathrm{km}^{2}\right)$ & 0.3861 & square mile $\left(\mathrm{mi}^{2}\right)$ \\
\hline
\end{tabular}




\title{
Surficial Geologic Map of the Norton-Manomet- Westport-Sconticut Neck 23-Quadrangle Area in Southeast Massachusetts
}

\author{
Compiled by Byron D. Stone, Janet R. Stone, Mary L. DiGiacomo-Cohen, and Kevin Kincare
}

\section{Introduction}

The surficial geologic map shows the distribution of nonlithified earth materials at land surface in an area of 23 7.5-minute quadrangles (919 $\mathrm{mi}^{2}$ total) in southeastern Massachusetts (fig. 1). Across Massachusetts, these materials range from a few feet to more than $500 \mathrm{ft}$ in thickness. They overlie bedrock, which crops out in upland hills and as resistant ledges in valley areas. The geologic map differentiates surficial materials of Quaternary age on the basis of their lithologic characteristics (such as grain size and sedimentary structures), constructional geomorphic features, stratigraphic relationships, and age. Surficial materials also are known in engineering classifications as unconsolidated soils, which include coarse-grained soils, fine-grained soils, and organic fine-grained soils. Surficial materials underlie and are the parent materials of modern pedogenic soils, which have developed in them at the land surface. Surficial earth materials significantly affect human use of the land, and an accurate description of their distribution is particularly important for assessing water resources, construction aggregate resources, and earthsurface hazards, and for making land-use decisions.

The mapped distribution of surficial materials that lie between the land surface and the bedrock surface is based on detailed geologic mapping of 7.5-minute topographic quadrangles, produced as part of an earlier (1938-1982) cooperative statewide mapping program between the U.S. Geological Survey and the Massachusetts Department of Public Works (now Massachusetts Department of Transportation, Highway Division) (Page, 1967; Stone, 1982). Each published geologic map presents a detailed description of local geologic map units, the genesis of the deposits, and age correlations among units. Previously unpublished field compilation maps exist on paper or mylar sheets and these have been digitally rendered for the present map compilation. Regional summaries based on the Massachusetts surficial geologic mapping studies discuss the ages of multiple glaciations, the nature of glaciofluvial, glaciolacustrine, and glaciomarine deposits, and the processes of ice advance and retreat across Massachusetts (Koteff and Pessl, 1981; papers in Larson and Stone, 1982; Oldale and Barlow, 1986; Stone and Borns, 1986; Warren and Stone, 1986).

This compilation of surficial geologic materials is an interim product that defines the areas of exposed bedrock and the boundaries between glacial till, glacial stratified deposits, and overlying postglacial deposits. The eastern part of this 23-quadrangle map differs from the rest of Massachusetts in that surficial moraine and stratified materials entirely cover the basal till and bedrock surfaces, which are shown on the basal layer of this map database. In addition, moraine deposits are more extensive and complex than in northern Massachusetts. This work is part of a comprehensive study to produce a statewide digital map of the surficial geology at a 1:24,000-scale level of accuracy. This surficial geologic map report covering 23 quadrangles revises previous 
digital surficial geologic maps (Stone and others, 1993; MassGIS, 1999) that were compiled on base maps at regional scales of 1:125,000 and 1:250,000. The purpose of this study is to provide fundamental geologic data for the evaluation of natural resources, hazards, and land information within the Commonwealth of Massachusetts.

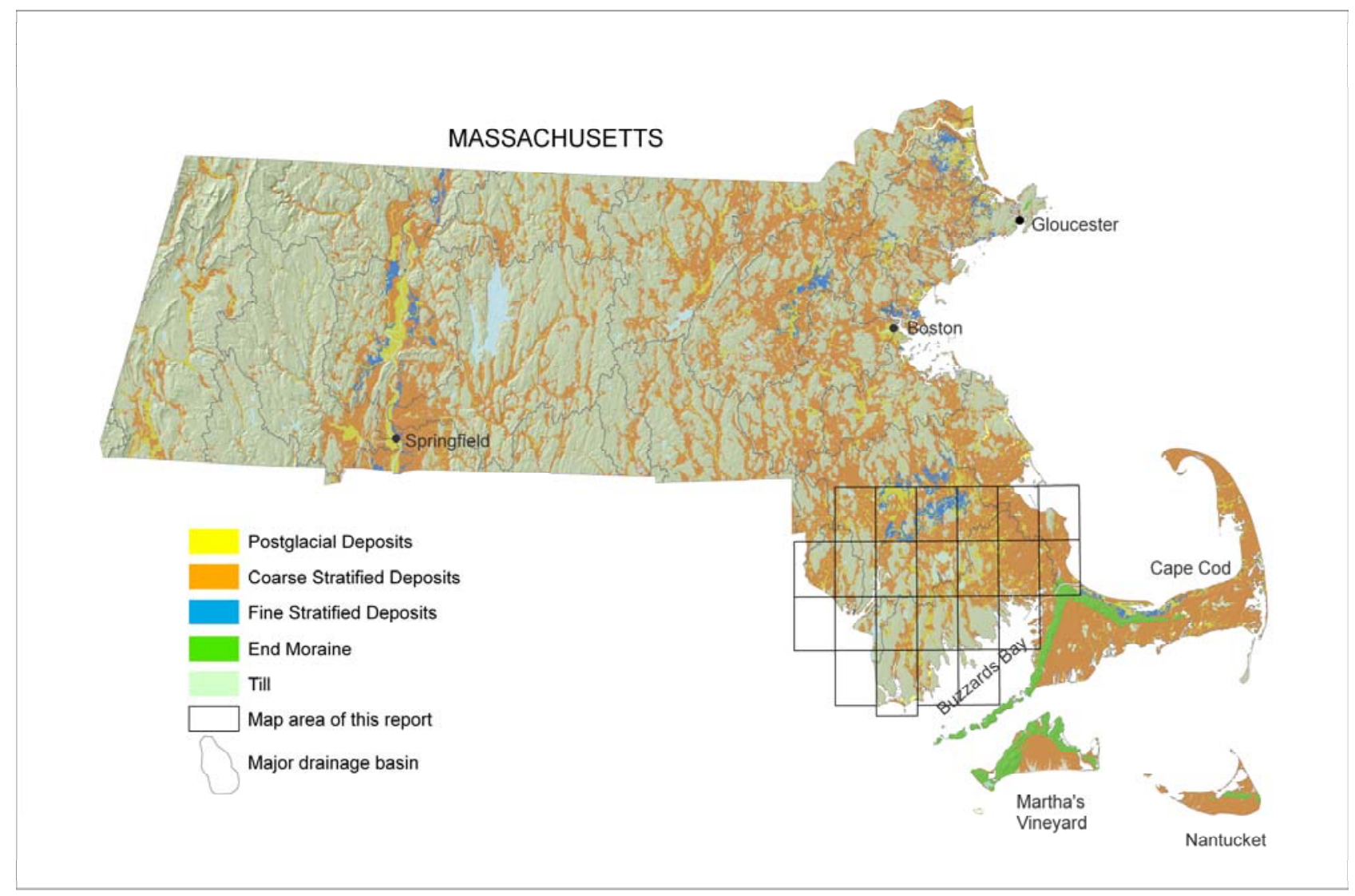

Figure 1. General distribution of glacial and postglacial deposits in Massachusetts (Stone and others, 1993; MassGIS, 1999) and 1:24,000-scale quadrangles covered by this report.

\section{Surficial Materials in Massachusetts}

Most of the surficial materials in Massachusetts are deposits of the last two continental ice sheets that covered all of New England in the latter part of the Pleistocene ice age (Schafer and Hartshorn, 1965; Oldale and others, 1982; Stone and Borns, 1986). In the southeastern region, the glacial deposits are divided into two broad categories, glacial till and glacial moraine deposits and glacial stratified deposits. Glacial till, the most widespread glacial deposit in the subsurface, was laid down directly on bedrock and on local, older deposits by glacier ice. Glacial moraine deposits accumulated in ice-walled lakes and streams and on stagnant, buried ice in front of the receding edge of the ice sheet during the last deglaciation. Small moraine deposits accumulated in scattered patches along the ice margin. Glacial stratified deposits in the eastern part of the map area were laid down by glacial meltwater in streams and lakes adjacent to large moraines or stagnant ice at the 
front of the retreating ice margin. To the west, stratified deposits accumulated within local stagnant ice-bounded basins, and in streams and lakes that occupied valleys and lowland areas in front of the retreating ice margin. Postglacial sediments, primarily floodplain alluvium, swamp deposits, and beach and dune deposits, make up a lesser proportion of the unconsolidated materials.

Glacial till deposits consist of nonsorted, generally nonstratified mixtures of mineral and rock particles ranging in grain size from clay to large boulders. The matrix of most tills is composed dominantly of fine sand and silt; it supports scattered gravel clasts and boulders. Boulders, within and on the surface of tills, range from sparse to abundant. Some tills contain lenses of sorted sand and gravel, and, less commonly, masses of laminated fine-grained sediments. The color and lithologic characteristics of till deposits vary across Massachusetts but generally reflect the composition of the local underlying and northerly adjacent bedrock, from which the till was derived. Till blankets the bedrock surface in variable thickness, ranging from a few inches to more than $200 \mathrm{ft}$, and commonly underlies stratified meltwater deposits. Tills deposited during the last two glaciations occur in superposition within Massachusetts (Koteff, 1966; Newton, 1978; Weddle and others, 1989). The upper till was deposited during the last (late Wisconsinan) glaciation; it is the most extensive till and commonly is observed in surface exposures, especially in areas where till thickness is less than 10 to $15 \mathrm{ft}$ (thin-till unit on the map). The lower till ("old" till) was deposited during an earlier glaciation (probably Illinoian) and has a more limited distribution; it is principally a subsurface deposit that constitutes the bulk of material in drumlins and other hills, where till thickness is greater than $15 \mathrm{ft}$. The distribution of lower till is shown primarily by the thick-till unit on the map. The lower till generally is overlain by a thin mantle of upper till in these areas. In all exposures in Massachusetts showing the superposed two tills, the base of the upper till truncates the weathered surface of the lower till. The lower part of the upper till commonly displays a zone of shearing, dislocation, and brecciation in which clasts of lower till were mixed and incorporated into the upper till during the last glaciation.

Glacial moraine deposits are scattered throughout a large part of the map area and are defined on the map as either end moraine or thrust-moraine deposits. Only one glacial thrust deposit occurs in the area, and it covers an extensive area just east of the town of Buzzard Bay, in the southern part of the Sagamore quadrangle and the northern part of the Pocasset quadrangle. This thrust-moraine deposit includes shallow surface layers of sandy and bouldery ablation till and local compact sandy till, and thick subsurface deposits composed of sorted and layered, glacially deformed meltwater sediments, as reported in drill hole descriptions. These thrust-moraine deposits form the Sandwich moraine (Oldale and O'Hara, 1984). End moraine deposits are composed of a surface layer, 6 to $30 \mathrm{ft}$ thick, of sandy and bouldery ablation till, local compact sandy till, or a layered, sandy and bouldery sediment of probable debris-flow origin. Sedimentary units in all of the large moraines have limited lateral extent and irregular thickness; stratification is deformed by collapse structures around kettle depressions and by glaciotectonic folds and thrust faults in some deposits. These deposits were laid down along active ice margins during retreat of the last (late Wisconsinan) ice sheet. Small moraines are present locally elsewhere in the western part of this map area, in the Boston area, and in the Gloucester-Rockport area (Gloucester quadrangle) of northeastern Massachusetts.

Glacial stratified deposits consist of layers of well-sorted to poorly sorted gravel, sand, silt, and clay laid down by flowing meltwater in glacial streams, lakes, and marine embayments that occupied the valleys and lowlands of Massachusetts during retreat of the last ice sheet. Textural variations within the meltwater deposits occur both areally and vertically because meltwater-flow regimes were different in glaciofluvial (stream), glaciodeltaic (where a stream entered a lake or the 
sea), glaciolacustrine (lake bottom), and glaciomarine (marine bottom) depositional environments. Grain-size variations also resulted from meltwater deposition in positions either proximal to, or distal from, the retreating glacier margin, which was the principal sediment source. A common depositional setting contained a proximal, ice-marginal meltwater stream in which horizontally bedded glaciofluvial gravel and (or) sand and gravel were laid down; farther downvalley, the stream entered a glacial lake where glaciodeltaic sediments were deposited, consisting of horizontally layered sand and gravel delta-topset beds overlying inclined layers of sand in deltaforeset beds. Farther out in the glacial lake, very fine sand, silt, and clay settled out on the lake bottom in flat-lying, thinly bedded glaciolacustrine layers. Thick sequences having these textural variations commonly are present in the vertical section of meltwater deposits across the State (Stone and others, 1992). Most of the meltwater sediments in Massachusetts were deposited in or graded to large and small glacial lakes. These large and small lakes formed in northerly sloping valleys and basins where they were dammed by the ice margin (ice-dammed lakes) and in southerly sloping valleys and basins where they were dammed by slightly older deltaic sediments or moraines (sediment-dammed lakes). Many of the coarse sediments in deltaic deposits and fine sediments in lake-bottom deposits shown in this map compilation are related to an extensive sediment-dammed lake, glacial Lake Narragansett, which expanded from the Narragansett Bay region of Rhode Island (Boothroyd, 2003; Boothroyd and August, 2008) into the coastal valleys of Block Island Sound, Buzzards Bay, and the Taunton River drainage basin in southeastern Massachusetts.

Detailed geologic maps typically show meltwater sedimentary units within each glacial lake or valley outwash system (Jahns, 1941, 1953; Koteff, 1966). These units, known as morphosequences (Koteff, 1974; Koteff and Pess1, 1981), are the smallest mappable stratigraphic units depictable on detailed geologic maps. Morphosequences are bodies of stratified meltwater sediments that are contained in a continuum of landforms, grading from ice-contact forms (eskers, kames) to non-ice-contact forms (flat valley terraces, delta plains) that were deposited simultaneously at and beyond the margin of the ice sheet, and were graded to a specific base level. Each morphosequence consists of a proximal part (head) deposited within or near the ice margin and a distal part deposited farther away from the ice margin. Both grain size and ice-melt collapse deformation of beds decrease from the proximal to the distal part of each morphosequence. The head of each morphosequence is either ice marginal (ice contact) or near ice marginal. The surface altitude of fluvial sediments in each morphosequence was controlled by a specific base level, either a glacial-lake or marine water plane or a valley knickpoint. Few morphosequences extend distally more than 6 miles; the glaciodeltaic outwash plains in the eastern part of this map area are some of the most extensive morphosequences in Massachusetts. Most morphosequences are less than 1 mile in length, as in the western part of this map area. In any one basin, individual morphosequences were deposited successively as the ice margin retreated systematically northward. Consequently, in many places the distal, finer grained facies of a younger morphosequence stratigraphically overlies the proximal, coarse-grained facies of a preceding morphosequence.

Figure 2 shows an example of the variability of sediment types in the subsurface of glacial stratified deposits. The figure schematically shows the relationship between coarse-grained deltaic deposits (sand and gravel and sand) and extensive fine-grained lake (or marine) deposits (fine sand, silt, and clay) in the subsurface. Such coarse- and fine-grained units are common in most of the valleys and lowlands of Massachusetts (Langer, 1979; Stone and others, 1979; Stone and others, 1992; Stone and others, 2005). On these interim maps of this report, coarse-grained and fine- 
grained textural variations within glacial stratified deposits are shown only where they occur at land surface. Subsurface textural variations are not shown.

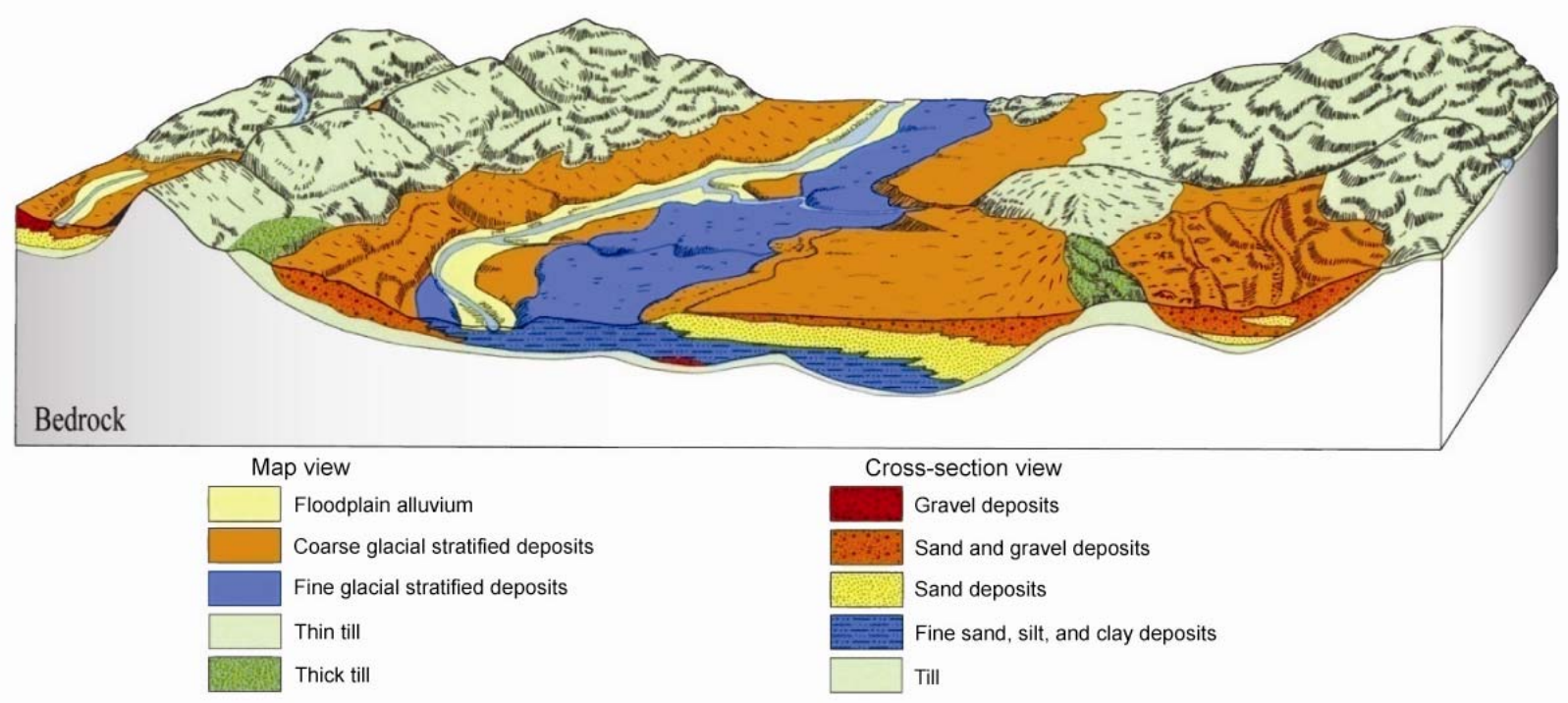

Figure 2. Block diagram illustrating the typical areal and vertical distribution of glacial and postglacial deposits overlying bedrock (modified from Stone and others, 1992).

The areal distribution of till and stratified deposits is related to the physiography of the State (fig. 1). The thickness of these materials varies considerably within these regions because of such factors as the high relief of the bedrock surface, changing environments of deposition during deglaciation, and various effects of postglacial erosion and removal of glacial sediments. In highland areas, notably in the western and central regions, till is the major surficial material and is present as a discontinuous mantle of variable thickness over the bedrock surface. Till is thickest in drumlins (reportedly as much as $230 \mathrm{ft}$ thick) and on the northwest slopes of most bedrock hills. Glacial meltwater deposits that average $50 \mathrm{ft}$ in thickness (Stone and others, 1993) overlie the till in small upland valleys and north-sloping basins between bedrock hills. Glacial stratified deposits are the predominant surficial materials in the Connecticut River valley, the northeastern and southeastern lowlands, and on Cape Cod and the islands. These deposits generally overlie till; however, well logs indicate that in some places till is not present and the stratified deposits lie directly on bedrock. On Cape Cod and the islands, glacial stratified deposits are 100 to $>500 \mathrm{ft}$ thick, and, combined with moraine deposits, completely cover the subsurface till, coastal plain deposits, and bedrock. In the southeastern lowland of Massachusetts shown on this map, and in parts of the Connecticut River valley, extensive stratified deposits also cover the bedrock surface.

Postglacial deposits locally overlie the glacial deposits throughout the State. Alluvium underlies the floodplains of most streams and rivers. Swamp and marsh deposits occur in low-lying, poorly drained areas in upland and lowland settings, but swamp deposits are shown only where they are estimated to be at least $3 \mathrm{ft}$ thick. Salt-marsh and estuarine deposits are present mainly along the tidal portions of streams and rivers entering the offshore areas. Beach and dune deposits occur along the shoreline. Deposits influenced by man, such as construction sites and cranberry bogs, also are shown. 


\section{Description of Map Units}

\section{Postglacial Deposits}

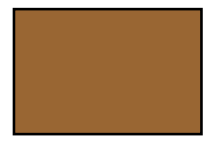

Artificial fill-Earth materials and manmade materials that have been artificially emplaced, primarily in highway and railroad embankments, and in dams; may also include landfills, urban development areas, and filled coastal wetlands

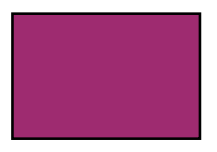

Cranberry bog-Some natural freshwater swamps or peat bogs overlain locally by artificially emplaced sand or other fill; in many places in southeastern Massachusetts, cranberry bogs are created by excavation into sand and gravel deposits that form the bed; peat and other organic material have been artificially emplaced over the bed and water drainage pathways are diverted into the area to control seasonal flooding of the bog

Alluvium-Sand, gravel, silt, and some organic material, stratified and well sorted to poorly sorted, beneath the floodplains of modern streams. The texture of alluvium commonly varies over short distances both laterally and vertically and generally is similar to the texture of adjacent glacial deposits. Along smaller streams, alluvium is commonly less than $5 \mathrm{ft}$ thick. The most extensive deposits of alluvium in the map area are along the Taunton, Threemile, Runnins, Palmer, and Acushnet Rivers. Alluvium overlies thicker stratified deposits; thin alluvial deposits probably lie beneath salt-marsh deposits in coastal valley reaches that were flooded during the postglacial rise of sea level

Swamp and marsh deposits - Organic muck and peat that contain minor amounts of sand, silt, and clay, stratified and poorly sorted, in freshwater swamps and marshes, kettle depressions, or poorly drained areas. Swamp and marsh deposits are shown only where they are estimated to be at least $3 \mathrm{ft}$ thick; most deposits are less than $10 \mathrm{ft}$ thick. Swamp and marsh deposits overlie glacial meltwater deposits and postglacial pond deposits in kettle depressions. They locally overlie glacial till in stream channels that have been eroded through thin glacial meltwater deposits

Salt-marsh deposits - Peat and organic muck interbedded with sand and silt, deposited in saltwater or brackish-water environments of low wave energy along the coast and in river estuaries. Salt-marsh deposits are generally a few feet to $25 \mathrm{ft}$ thick. In the major estuaries, these deposits locally overlie estuarine deposits (not mapped), which are sand and silt with minor organic material as much as 30 to $80 \mathrm{ft}$ thick. The salt-marsh and estuarine deposits generally are underlain by adjacent glacial stratified deposits 
Beach and dune deposits - Sand and fine gravel deposited along the shoreline by waves and currents and by wind action. The texture of beach deposits varies over short distances and is generally controlled by the texture of nearby glacial materials exposed to wave action. Sand beach deposits are composed of moderately sorted, very coarse to fine sand, commonly laminated. Coarser layers locally contain some fine gravel particles; finer layers contain some very fine sand and silt. Gravel beach deposits are composed of granule- to cobble-size clasts in moderately sorted thin beds; deposits contain minor amounts of sand within gravel beds and thin beds of sand as alternating layers. Beach deposits are rarely more than a few feet thick. Dune deposits are composed of moderately to well-sorted, fine to medium sand, variably massive, laminated, and crossbedded. Dune deposits are as much as $50 \mathrm{ft}$ thick. Unit includes artificial sand deposits in locally replenished beaches

\section{Glacial Stratified Deposits}

Sorted and stratified sediments composed of gravel, sand, silt, and clay (as defined in particle-size diagram, fig. 3) deposited in layers by glacial meltwater. These sediments occur as four basic textural units - gravel deposits, sand and gravel deposits, sand deposits, and fine deposits. On this interim surficial geologic map layer, gravel, sand and gravel, and sand deposits are not differentiated and are shown as Coarse deposits where they occur at land surface. Stagnantice deposits are surface coarse sediments bounded by ice-contact slopes, present on tops of till hills or extending $>30 \mathrm{ft}$ above the altitudes of adjacent meltwater morphosequences in lowlands. These stagnant-ice deposits are aligned in belts parallel to the retreating ice margin. Fine deposits also are shown where they occur at land surface. Textural changes occur both areally and vertically (fig. 2); however, subsurface textural variations are not shown on this map.

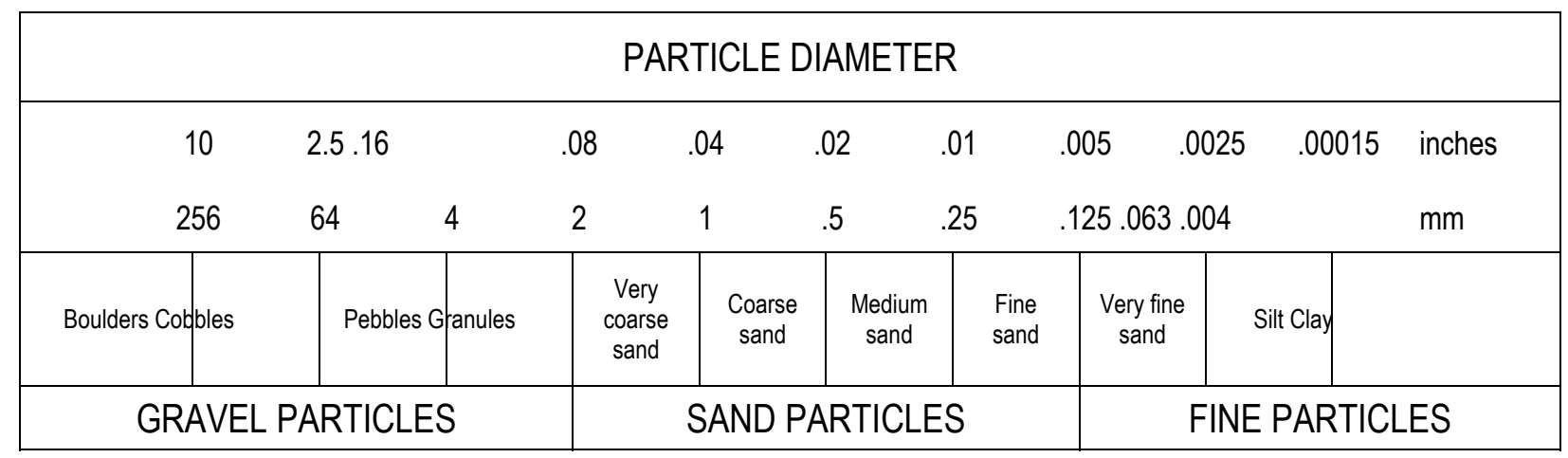

Figure 3. Grain-size classification used in this report, modified from Wentworth (1922). 
Coarse deposits include gravel deposits composed of at least 50 percent gravel-size clasts; cobbles and boulders predominate; minor amounts of sand occur within gravel beds, and sand comprises few separate layers. Gravel layers generally are poorly sorted, and bedding commonly is distorted and faulted due to postdepositional collapse related to melting of ice. Sand and gravel deposits occur as mixtures of gravel and sand within individual layers and as layers of sand alternating with layers of gravel. Sand and gravel layers generally range from 25 to 50 percent gravel particles and from 50 to 75 percent sand particles. Layers are well to poorly sorted; bedding may be distorted and faulted due to postdepositional collapse. Sand deposits are composed mainly of very coarse to fine sand, commonly in well-sorted layers. Coarser layers may contain up to 25 percent gravel particles, generally granules and pebbles; finer layers may contain some very fine sand, silt, and clay

Fine deposits include very fine sand, silt, and clay that occur as well-sorted, thin layers of alternating silt and clay (varves) or as thicker layers of very fine sand and silt. Very fine sand commonly occurs at the surface and grades downward into rhythmically bedded silt and clay varves. In some places on the lake-bottom surface of glacial Lake Narragansett, fine deposits are overlain by as much as $30 \mathrm{ft}$ of fine to medium sand, deposited as the lake became shallower; this sand has not been mapped separately

Stagnant-ice deposits - Surface coarse sediments include scattered large surface boulders, gravel deposits and sand and gravel deposits, totaling 5 to $30 \mathrm{ft}$ thick, that overlie chiefly sand deposits. Sand deposits contain deltaic foreset bedding and interlayered beds of fine sand, silt, and little clay. Sand and silty sand deposits extend downward to basal till and bedrock. Flowtill sediments are interlayered under ice-contact slopes. Stratification in surface and underlying sediments is generally distorted and faulted due to postdepositional collapse related to melting of buried ice. Stagnant-ice deposits are confined to irregular hummocky hills, bounded by icecontact slopes, present on tops of till hills or extending $>30 \mathrm{ft}$ above the altitudes of adjacent meltwater morphosequences in lowlands. Deposits are aligned in belts parallel to the retreating ice margin

\section{Glacial Till and Moraine Deposits}

Thin till-Nonsorted, nonstratified matrix of sand, some silt, and little clay containing scattered gravel clasts and few large boulders; predominantly upper till of the last glaciation; loose to moderately compact, generally sandy, commonly stony. Till is mapped where it is generally less than 10 to $15 \mathrm{ft}$ thick including areas of shallow bedrock. Two facies are present in some places: a looser, coarser grained ablation facies, melted out from supraglacial position; and an underlying more compact, finer grained lodgement facies deposited subglacially. Both ablation and lodgement facies of upper till are sandy and stony and are derived from coarsegrained crystalline rocks. Subsurface till overlies fresh, nonweathered bedrock; this basal till varies in known thickness from $<5$ to $>50 \mathrm{ft}$ (Williams and Willey, 1973; 
Williams and Tasker, 1974; Hansen and Lapham, 1992; Masterson and others, 1997). Till may overlie older Pleistocene deposits locally

Thick till-Nonsorted, nonstratified matrix of sand, some silt, and little clay containing scattered pebbles, cobbles, and boulders in the shallow subsurface; at greater depths consists of compact, nonsorted matrix of silt, very fine sand, and some clay containing scattered small gravel clasts. Mapped in areas where till is greater than 10 to $15 \mathrm{ft}$ thick, chiefly in drumlin landforms in which till thickness commonly exceeds $100 \mathrm{ft}$ (maximum recorded thickness is $230 \mathrm{ft}$ ). Although upper till is the surface deposit, the lower till constitutes the bulk of the material in these areas. Lower till is moderately to very compact and is commonly finer grained and less stony than upper till. An oxidized zone, the lower part of a soil profile formed during a period of interglacial weathering, is generally present in the upper part of the lower till. This zone commonly shows closely spaced joints that are stained with iron and manganese oxides

Till overlying sand deposits-In the Pine Hills area, Manomet quadrangle, surface deposits of till and overlying thin colluvium, both consisting of a nonsorted, nonstratified matrix of sand, some silt, and little clay containing scattered gravel clasts and few large boulders; loose to moderately compact, generally sandy, commonly stony. The surface nonsorted deposits, 6 to $30 \mathrm{ft}$ thick, overlie sand, gravel, and silty sand deposits that extend $>250 \mathrm{ft}$ downward to basal till and bedrock (Hansen and Lapham, 1992). These subsurface stratified deposits crop out in the sides of Pine Hills and Indian Hill, where they appear to be coarse-grained glacial meltwater sediments

End moraine deposits - Composed predominantly of boulders and ablation facies sandy upper till; lenses of stratified sand and gravel occur locally within the till. Surface boulders on end moraine deposits are generally more numerous than on adjacent till surfaces; dense concentrations of boulders are present in some places. Deposits occur as free-standing hummocky landforms, commonly in ridges that trend ENE - WSW, and range in thickness from 10 to $60 \mathrm{ft}$

Thrust-moraine deposits - Surface deposits of nonsorted, nonstratified matrix of sand, some silt, and little clay containing scattered gravel clasts and large boulders; predominantly till of the last glaciation; loose to moderately compact, generally sandy, commonly stony. Two facies of till are present in some places: a looser, coarser grained ablation facies, melted out from supraglacial position; and an underlying more compact, finer grained lodgement facies deposited subglacially (Oldale, 1975). Both ablation and lodgement facies of till are stony, containing boulders, and are derived from coarse-grained crystalline rocks. The surface nonsorted deposits, 6 to $30 \mathrm{ft}$ thick, overlie sand, gravel, and silty sand sediments that compose the large meltwater deposit extending to the south and downward to basal till and bedrock. Surface deposits and stratification in underlying sediments commonly are distorted and faulted due to readvance of the ice margin (Oldale and O'Hara, 1984) postdepositional collapse related to melting of buried ice 


\section{Bedrock Areas}

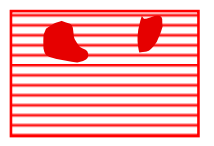

Bedrock outcrops and areas of abundant outcrop or shallow bedrock-Solid color shows extent of individual bedrock outcrops; line pattern indicates areas of shallow bedrock or areas where small outcrops are too numerous to map individually; in areas of shallow bedrock, surficial materials are less than 5 to $10 \mathrm{ft}$ thick. These units are not mapped consistently among all quadrangles; see appendix for detail of bedrock outcrop mapping in each quadrangle

\section{Map Compilation}

This compilation is the seventh in a series of interim products and shows surficial geology in an area of 23 7.5-minute quadrangles in southeastern Massachusetts. The quadrangles are Norton, Taunton, Bridgewater, Plympton, Plymouth, Manomet, East Providence, Somerset, Assonet, Assawompset Pond, Snipatuit Pond, Wareham, Sagamore, Bristol, Fall River, Fall River East, New Bedford North, Marion, Onset, Tiverton, Westport, New Bedford South, and Sconticut Neck (fig. 4; fig. 5, area F). Also included in this report is the northern end of the Pocasset quadrangle; the portion lying north and west of the Cape Cod Canal was not published as part of Open-File Report 2006-1260-E. Figure 5 shows all of the compilation areas for surficial geology in Massachusetts. The surficial geologic maps are being produced sequentially by letter designation (although publication of area $\mathrm{G}$ preceded that of area F).

The surficial geologic map was compiled in several steps:

1) Paper copies of the published surficial geologic maps for four quadrangles were scanned and georeferenced by MassGIS;

2) The Office of the Massachusetts State Geologist (now the Massachusetts Geological Survey) vectorized the georeferenced images in order to digitally retain the original linework of the published maps (Mabee and others, 2004);

3) Digital geologic map units were compiled and grouped into basic units in three shapefile layers: Postglacial deposits including artificial fill, swamp and marsh deposits, cranberry bogs, beach and dune deposits, and alluvium; glacial stratified deposits including coarsegrained, stagnant-ice, and fine-grained deposits; and glacial till, moraine deposits, and bedrock including deposits of thin till, thick till (drumlins), end moraine, thrust moraine, till overlying sand, and outcrops and areas of shallow bedrock. The distribution of glacial stratified deposits beneath adjacent overlying postglacial deposits and water bodies was inferred by the compilers;

4) The same basic units as those listed above were compiled and digitized for 19 unpublished quadrangles from scanned field maps by U.S. Geological Survey personnel;

5) The 23 individual quadrangle maps were joined and edge-matched in order to form a seamless digital geologic map. Discrepancies along quadrangle boundaries were resolved, and thick-till areas and shallow bedrock areas were added by the compilers in quadrangles where these units had not been previously mapped. 


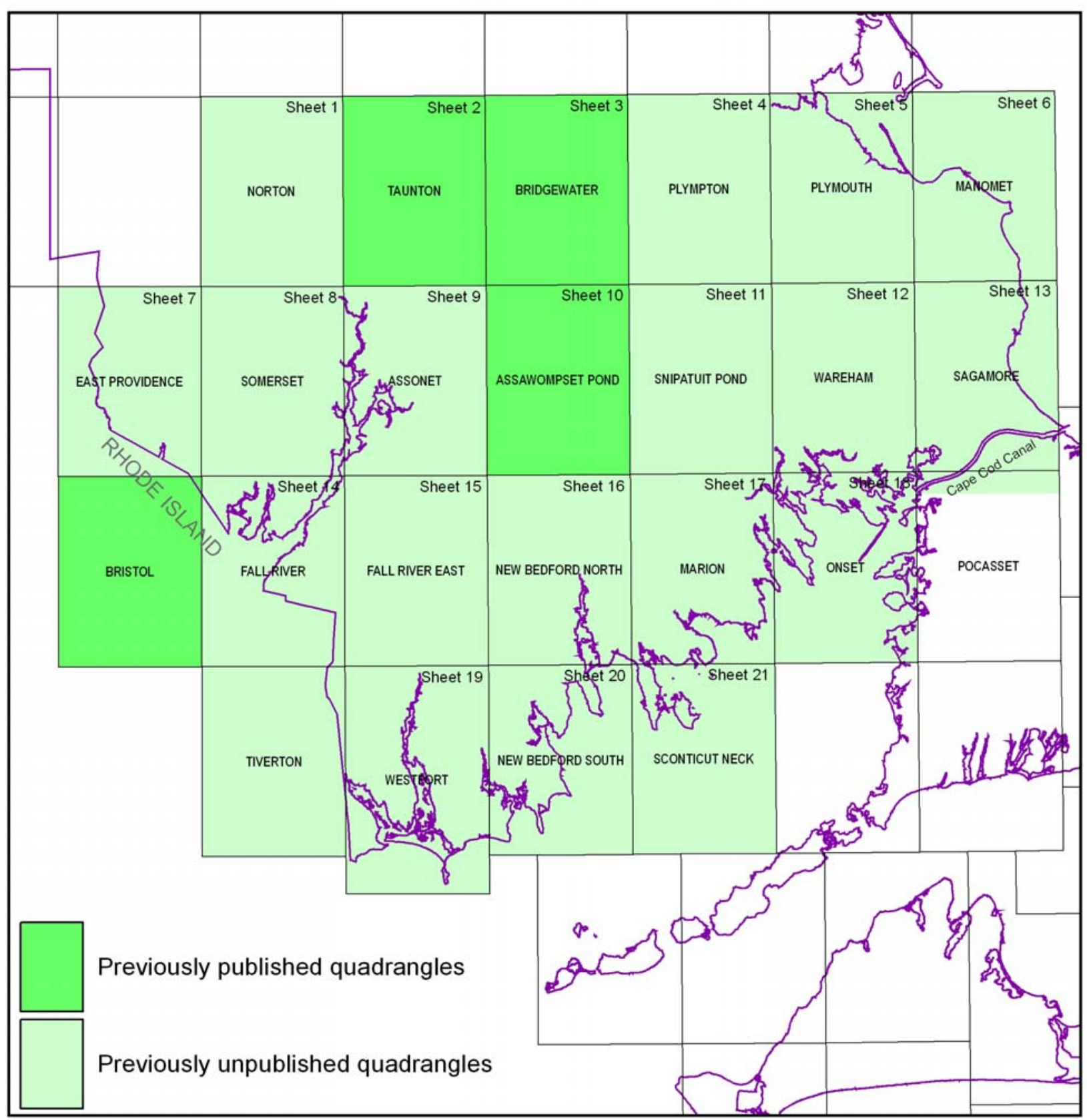

Figure 4. The 23 USGS 7.5-minute, 1:24,000-scale quadrangles in this compilation. Sheet numbers refer to the 21 Adobe PDF map files of individual quadrangles. The Massachusetts part of the Bristol quadrangle is shown with the East Providence quadrangle on sheet 7 , and the Tiverton quadrangle is shown with the Westport quadrangle on sheet 19. The northern portion of the Pocasset quadrangle is shown with the Sagamore quadrangle on sheet 13; the remainder of the Pocasset quadrangle was mapped and included in Open-File Report 2006-1260-E.

All geologic mapping was completed at 1:24,000 scale. The 1:24,000-scale, 10-ft contour interval topographic base maps (1955-1972 editions) used for this mapping effort are included as part of the digital data package in the 24k_basemaps folder. The GIS folder included with this 
report contains three ArcGIS shapefiles, which show the distribution of geologic units that cover the entire map area and are intended for use at quadrangle scale. The shapefiles can be clipped by quadrangle or by town boundaries. Unlike the units in conventional geologic maps, the digitally defined map units are arranged in layers according to superposition. The shapefile for till, moraine deposits, and bedrock is the bottom layer, which is overlain by the succeeding stratified deposits shapefile layer; these materials are shown everywhere they occur, including beneath postglacial deposits, such as swamp deposits and floodplain alluvium, and also beneath water bodies. The shapefile for postglacial deposits is the top layer because these materials overlie the older materials in the other two layers. Instructions for using the digital files are included in the README file and metadata.

In addition to the seamless digital layers that cover the entire compilation area, Adobe PDF map files of the surficial geology layers shown with 1:24,000-scale topographic base-map images have been generated for each quadrangle (see sheets 1-21, fig 4.).

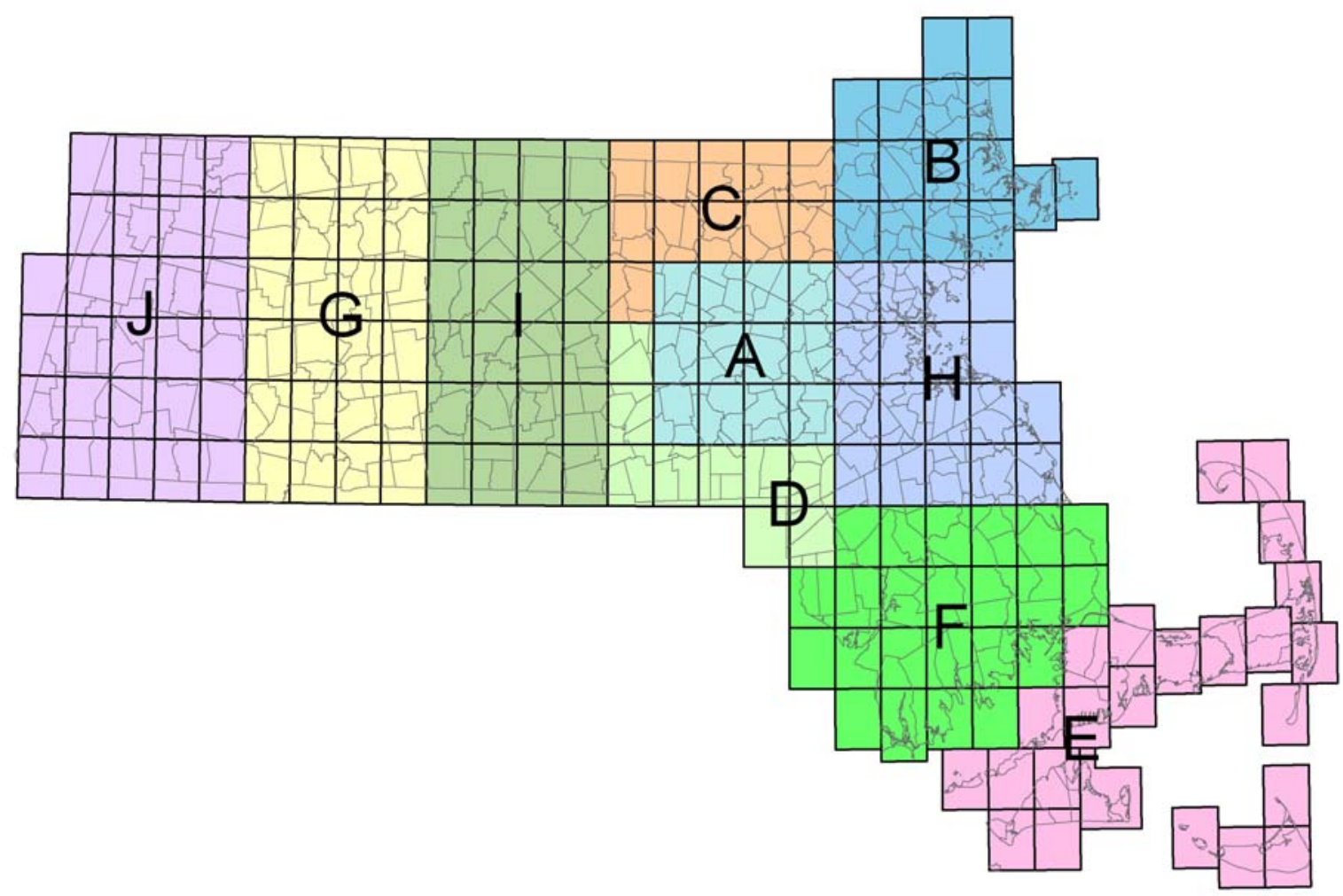

Figure 5. Compilation areas in Massachusetts. Letters represent sections of Open-File Report 20061260. Sections published to date are available online at $h$ ttp://pubs.usgs.gov/of/2006/1260/. 


\section{References Cited}

Boothroyd, J.C, 2003, Quaternary geologic mapping in an urban environment [abs.]: Geological Society of America Abstracts with Programs, v. 38, p. 78.

Boothroyd, J.C., and August, P.V., 2008, Geological and contemporary landscapes of the Narragansett Bay ecosystem, in Desbonnet, A., and Costa-Pierce, B.A., eds., Science for ecosystem-based management; Narragansett Bay in the 21st century, New York, N.Y., Springer, p. 1-33.

Hansen, B.P., and Lapham, W.W., 1992, Geohydrology and simulated ground-water flow, Plymouth-Carver Aquifer, southeastern Massachusetts: U.S. Geological Survey Water-Resources Investigations Report 90-4204, $91 \mathrm{p}$.

Hartshorn, J.H., 1960, Geology of the Bridgewater quadrangle, Massachusetts: U.S. Geological Survey Geologic Quadrangle Map GQ-127, scale 1:24,000.

Hartshorn, J.H., 1967, Geology of the Taunton quadrangle, Bristol and Plymouth Counties, Massachusetts: U.S. Geological Survey Bulletin 1163-D, scale 1:24,000.

Jahns, R.H., 1941, Outwash chronology in northeastern Massachusetts [abs.]: Geological Society of America Bulletin, v. 52, no. 12, pt. 2, p. 1910.

Jahns, R.H., 1953, Surficial geology of the Ayer quadrangle, Massachusetts: U.S. Geological Survey Geologic Quadrangle Map GQ-21, scale 1:31,680.

Koteff, Carl, 1964, Geologic map of the Assawompset Pond quadrangle, Massachusetts: U.S. Geological Survey Geologic Quadrangle Map GQ-265, scale 1:24,000.

Koteff, Carl, 1966, Surficial geologic map of the Clinton quadrangle, Worcester County, Massachusetts: U.S. Geological Survey Geologic Quadrangle Map GQ-567, scale 1:24,000.

Koteff, Carl, 1974, The morphologic sequence concept and deglaciation of southern New England, in Coates, D.R., ed., Glacial geomorphology: Binghamton, N.Y., State University of New York, Annual Geomorphology Symposia Series, Proceedings, v. 5, p. 121-144.

Koteff, Carl, and Pessl, Fred, Jr., 1981, Systematic ice retreat in New England: U.S. Geological Survey Professional Paper 1179, 20 p.

Langer, W.H., 1979, Map showing distribution and thickness of the principal fine-grained deposits, Connecticut Valley urban area, central New England: U.S. Geological Survey Miscellaneous Investigations Series Map I-1074-C, 2 sheets, scale 1:125,000.

Larson, G.J., 1982, Nonsynchronous retreat of ice lobes from southeastern Massachusetts, in Larson, G.J., and Stone, B.D., eds., 1982, Late Wisconsinan glaciation of New England: Dubuque, Iowa, Kendall/Hunt, p. 101-114.

Larson, G.J., and Stone, B.D., eds., 1982, Late Wisconsinan glaciation of New England: Dubuque, Iowa, Kendall/Hunt, 252 p.

Lyons, P.C., 1977, Report on the bedrock geology of the Narragansett Basin, Massachusetts and Rhode Island, U.S. Geological Survey Open-File Report 77-816, scale 1:31,250.

Mabee, S.B., Stone, B.D., and Stone, J.R., 2004, Precise conversion of paper geologic maps to value-added digital products; the Massachusetts method for surficial geology [abs.]: Geological Society of America Abstracts with Programs, v. 36, no. 2, p. 78.

MassGIS (Massachusetts Office of Geographic Information), 1999, Surficial geology (1:250,000), October 1999 [statewide data layer]: Vector digital data available at http://www.mass.gov/mgis/sg.htm.

Masterson, J.D., Stone, B.D., Walter, D.R., and Savoie, J., 1997, Water resources of western Cape Cod: U.S. Geological Survey Hydrologic Atlas HA-741, map scale 1:48,000. 
Mather, K.F., Goldthwait, R.P., and Theismeyer, L.R., 1942, Pleistocene geology of western Cape Cod, Massachusetts: Geological Society of America Bulletin v. 53, p. 1127-1174.

Newton, R.M., 1978, Stratigraphy and structure of some New England tills: Amherst, Mass., University of Massachusetts, unpublished Ph.D. dissertation, 256 p.

Oldale, R.N., 1975, Geologic map of the Sandwich quadrangle, Barnstable County, Cape Cod, Massachusetts: U.S. Geological Survey Geologic Quadrangle Map GQ-1222, scale 1:24,000.

Oldale, R.N., and Barlow, R.A., 1986, Geologic map of Cape Cod and the Islands, Massachusetts: U.S. Geological Survey Miscellaneous Investigations Series Map I-1763, 1 sheet, scale $1: 100,000$.

Oldale, R.N., and O'Hara, C.J., 1984, Glaciotectonic origin of the Massachusetts coastal end moraines and a fluctuating late Wisconsinan ice margin: Geological Society of America Bulletin, v. 95, p. 61-74.

Oldale, R.N., Valentine, P.C., Cronin, T.M., Spiker, E.C., Blackwelder, B.W., Belknap, D.F., Wehmiller, J.F., and Szabo, B.J., 1982, Stratigraphy, structure, absolute age, and paleontology of the upper Pleistocene deposits at Sankaty Head, Nantucket Island, Massachusetts: Geology, v. 10 , no. 5 , p. $246-252$.

Page, L.R., 1967, The role of the United States Geological Survey in Massachusetts, in Farquhar, O.C., ed., Economic geology in Massachusetts: Amherst, Mass., University of Massachusetts, p. 9-28.

Schafer, J.P., and Hartshorn, J.H., 1965, The Quaternary of New England, in Wright, H.E., Jr., and Frey, D.G., eds., The Quaternary of the United States: Princeton, N.J., Princeton University Press, p. 113-128.

Smith, J.H., 1955, Surficial geology of the Bristol quadrangle and vicinity, Rhode Island and Massachusetts: U.S. Geological Survey Geologic Quadrangle Map GQ-70, scale 1:31,680.

Stone, B.D., 1982, The Massachusetts State surficial geologic map, in Farquhar, O.C., ed.,

Geotechnology in Massachusetts: Boston, University of Massachusetts, p. 11-28.

Stone, B.D., Beinikis, A.I., and Foster, Richard, 1993, Sand and gravel resources of Massachusetts: Boston, Massachusetts, New England Governors' Conference, 2 map sheets, scale 1:250,000.

Stone, B.D., and Borns, H.W., Jr., 1986, Pleistocene glacial and interglacial stratigraphy of New England, Long Island, and adjacent Georges Bank and Gulf of Maine, in Sibrava, Vladimir, Bowen, D.Q., and Richmond, G.M., eds., Quaternary glaciations in the Northern Hemisphere: Quaternary Science Reviews, v. 5, p. 39-52.

Stone, B.D., and Peper, J.D., 1982, Topographic control of the deglaciation of eastern Massachusetts: Ice lobation and the marine incursion, in Larson, G.J., and Stone, B.D., eds., Late Wisconsinan glaciation of New England: Dubuque, Iowa, Kendall/Hunt, p. 145-166.

Stone, J.R., London, E.H., and Langer, W.H., 1979, Map showing textures of unconsolidated materials, Connecticut Valley urban area, central New England: U.S. Geological Survey Miscellaneous Investigations Series Map I-1074-B, 3 sheets, scale 1:125,000.

Stone, J.R., Schafer, J.P., London, E.H., and Thompson, W.B., 1992, Surficial materials map of Connecticut: U.S. Geological Survey Special Map, 2 sheets, scale 1:125,000.

Stone, J.R., Schafer, J.P., London, E.H., DiGiacomo-Cohen, M.L., Lewis, R.L., and Thompson, W.B., 2005, Quaternary geologic map of Connecticut and Long Island Sound basin: U.S. Geological Survey Scientific Investigations Map 2784, 2 sheets, scale 1:125,000, 72-p. pamphlet. Warren, C.R., and Stone, B.D., 1986, Deglaciation stratigraphy, mode and timing of the eastern flank of the Hudson-Champlain lobe in western Massachusetts, in Cadwell, D.H., ed., The 
Wisconsinan Stage of the First Geological District, eastern New York: New York State Museum Bulletin, v. 455, p. 168-192.

Weddle, T.K., Stone, B.D., Thompson, W.B., Retelle, M.J., Caldwell, D.W., and Clinch, J.M., 1989, Illinoian and late Wisconsinan tills in eastern New England; transect from northeastern Massachusetts to west-central Maine, Trip A-2, in Berry, A.W., Jr., ed., Guidebook for field trips in southern and west-central Maine: New England Intercollegiate Geological Conference, p. 2585.

Wentworth, C.K., 1922, A scale of grade and class terms for clastic sediments: Journal of Geology, v. 30, no. 5, p. 377-392.

Willey, R.E., Williams, J.R., and Tasker, G.D., 1978, Water resources of the coastal drainage basins of southeastern Massachusetts, Westport River, Westport to Seekonk; U.S. Geological Survey Hydrologic Atlas HA-275, 5 maps.

Williams, J.R., and Willey, R.E., 1973, Bedrock topography and texture of unconsolidated deposits, Taunton River basin, southeastern Massachusetts; U.S. Geological Survey Miscellaneous Geologic Investigations Map I-742, scale 1:48,000.

Williams, J.R., and Tasker, G.D., 1974, Water resources of the coastal drainage basins of southeastern Massachusetts, Plymouth to Weweantic River, Wareham: U.S. Geological Survey Hydrologic Atlas HA-507, 2 maps.

Williams, J.R., and Tasker, G.D., 1978, Water resources of the coastal drainage basins of southeastern Massachusetts, northwest shore of Buzzards Bay: U.S. Geological Survey Hydrologic Atlas HA-560, 5 maps. 


\section{Appendix}

\section{Sources of Data by 7.5-Minute Quadrangle}

\section{Norton Quadrangle}

Stone, B.D., and Peper, J.D. (1982, unpublished field compilation map). Glacial stratified deposits include predominantly coarse-grained glaciofluvial and glaciodeltaic sediments graded to small glacial lakes in the Threemile River and Wading River valleys, Palmer River, Segreganset River, Canoe River, Rumford River valleys, and sediments graded to glacial Lake Narragansett in the middle Threemile River and Mulberry Meadow Brook valleys. Thick-till areas were delineated based on topographic analysis and subsurface data of Williams and Willey (1973). Distribution of bedrock outcrops is from Williams and Willey (1973), Lyons (1977), Willey and others (1978), and Stone and Peper in 1982 (unpublished). The shallow-bedrock unit represents areas of small scattered bedrock outcrops. Additional bedrock outcrops and shallow-bedrock areas are most likely present, particularly in areas of thin till with steep slopes and irregular topography. Some postglacial units were mapped using 2005 orthophoto images.

\section{Taunton Quadrangle}

Map units were modified from Hartshorn (1967). Glacial stratified deposits include predominantly coarse-grained glaciofluvial and glaciodeltaic sediments mapped as a group of glaciofluvial landforms (units Qic, Qk, Qkt, Qkp, Qow, Qgf) included in glaciofluvial deposits and kame delta (unit Qkd, in glaciolacustrine deposits) of Hartshorn (1967). These deposits were graded to glacial Lake Narragansett in the Taunton River lowland. Stagnant-ice deposits include coarse-grained glaciofluvial and glaciodeltaic sediments, flowtill deposits and boulders, mapped as kame deposits (unit Qk) of Hartshorn (1967). The thick-till unit is from the Qd (drumlin) unit of Hartshorn (1967). Additional areas of thick till may be expected beneath smooth slopes on the northerly sides of bedrock hills. Distribution of bedrock outcrops is from Hartshorn (1967) and Williams and Willey (1973). The shallow-bedrock unit represents areas of numerous exposures. Some postglacial units were mapped using 2005 orthophoto images.

\section{Bridgewater Quadrangle}

Map units were modified from Hartshorn (1960). Glacial stratified deposits include predominantly coarse-grained glaciofluvial and glaciodeltaic sediments mapped as a group of glaciofluvial landforms (units Qic, Qk, Qkt, Qkp, Qow, Qgf) included in glaciofluvial deposits and kame delta (unit Qkd) glaciolacustrine deposits of Hartshorn (1960). These deposits were graded to glacial Lake Narragansett in the Taunton River lowland and to local glacial lakes in the Nemasket River lowland in the southeastern part of the map area. Stagnant-ice deposits include coarse-grained glaciofluvial and glaciodeltaic sediments, flowtill deposits and boulders, mapped as kame deposits (unit Qk) of Hartshorn (1960). Additional areas of thick till may be expected beneath smooth slopes on the northerly sides of bedrock hills. Distribution of bedrock outcrops is from Hartshorn (1960). 
The shallow-bedrock unit represents areas of numerous exposures. Some postglacial units were mapped using 2005 orthophoto images.

\section{Plympton Quadrangle}

Goldthwait, R.P., and Thiesmeyer, L.R. (1940, unpublished field map); and Stone B.D., and Kincare, K.A. (2010, unpublished field compilation map). Glacial stratified deposits include predominantly coarse-grained glaciofluvial and glaciodeltaic sediments mapped as part of the Carver outwash plain (Mather and others, 1942; Larson, 1982) in the southeastern part of the area, as kames and kame deltas in the northeastern part of the area, and as kames and kame deltas that were graded to glacial Lake Narragansett in the Taunton River lowland (Larson, 1982; Stone and Peper, 1982). Other parts of these deposits were graded to local glacial lakes in the Shorts Brook and upper Winnetuxet River lowlands in the southwestern and central parts of the map area. The thick-till area was delineated based on its topographic expression. Distribution of bedrock outcrops is from Williams and Willey (1973) and Lyons (1977). Some postglacial units were mapped using 2005 orthophoto images.

\section{Plymouth Quadrangle}

Thiesmeyer, L.R. (1940, unpublished field map); and Stone and Kincare (2010, unpublished field map). Glacial stratified deposits include predominantly coarse-grained glaciofluvial and glaciodeltaic sediments mapped as part of the Wareham, King's Pond, and Carver outwash plains and the collapsed sand and gravel sediments of the Ellisville and Hog Rock moraines (Mather and others, 1942; Larson, 1982) in the southwestern part of the area, as deposits of the Plymouth kame field in the northeastern part of the area, and as kames and kame deltas graded to glacial Lake Narragansett in the Jones River lowland (Lake Taunton of Larson, 1982; Stone and Peper, 1982). Small moraine deposits composed of till overlying gravel and sand are modified from deposits of the Monk's Hill moraine of Thiesmeyer (1940, unpublished). Distribution of bedrock outcrops is from L.R. Thiesmeyer (1940, unpublished) and Stone and Kincare (2010, unpublished). The shallow-bedrock unit represents areas of small scattered bedrock outcrops. Some postglacial units and bedrock outcrops were mapped using 2005 orthophoto images.

\section{Manomet Quadrangle}

Goldthwait, R.P., and Thiesmeyer, L.R (1940, unpublished field map); and Stone B.D., and Kincare, K.A. (2010, unpublished field map). Glacial stratified deposits include predominantly coarse-grained glaciofluvial and glaciodeltaic sediments, mapped as part of the Wareham outwash plain. These deposits also include the collapsed sand and gravel sediments of the Ellisville moraine (Mather and others, 1942; Larson, 1982) in the southwestern part of the area, deposits of the Plymouth kame field in the northwestern part of the area, and kames and kame deltas graded to Lake Cape Cod Bay (Larson, 1982; Stone and Peper, 1982) in the eastern part of the area. The till overlying sand deposits beneath Pine Hills, Indian Hill, and Telegraph Hill are known from geophysical studies and drill-hole samples (Hansen and Lapham, 1992) and exposures in the sides of the hills. Some postglacial units mapped using 2005 orthophoto images. 


\section{East Providence Quadrangle}

Stone, B.D. (1982, unpublished field map). Glacial stratified deposits include predominantly coarse-grained glaciofluvial and glaciodeltaic sediments graded to glacial Lake Narragansett in the Runnins River, Ten Mile River, and Palmer River lowlands. Thick-till areas were delineated based on topographic analysis. Distribution of bedrock outcrops is from Willey and others (1978), Lyons (1977), and Stone (1982). The shallow bedrock unit represents areas of numerous outcrops. Additional bedrock outcrops and shallow-bedrock areas are likely present, particularly in areas of thin till that have steep slopes and irregular topography. Some postglacial units were mapped using 2005 orthophoto images.

\section{Somerset Quadrangle}

Peper, J.D., and Stone, B.D. (1982, unpublished field map). Glacial stratified deposits include predominantly coarse-grained glaciofluvial and glaciodeltaic sediments graded to glacial Lake Narragansett in the Palmer River, Cole River, and Taunton River valleys, and small glacial lakes in the upper Rocky Run, upper Cole River, and Segregansett River basins. Thick-till areas were delineated based on topographic analysis. Distribution of bedrock outcrops is from Willey and others (1978), Williams and Willey (1973), Lyons (1977), and Peper and Stone (1982, unpublished). The shallow bedrock unit represents areas of numerous outcrops. Some postglacial units were mapped using 2005 orthophoto images.

\section{Assonet Quadrangle}

Stone, B.D. (1982, unpublished field map). Glacial stratified deposits include predominantly coarse-grained glaciofluvial and glaciodeltaic sediments graded to glacial Lake Narragansett in the Taunton River and Assonet River valleys. Distribution of bedrock outcrops is from Williams and Willey (1973), Lyons (1977), and Stone (1982, unpublished). Thick-till areas were delineated based on topographic analysis. The shallow bedrock unit represents areas of abundant outcrop but is shown only where the bedrock mapper made structural measurements. Some areas of shallow bedrock were added to those shown on the published map using topographic analysis, but significant additional areas of shallow bedrock and bedrock outcrops occur, particularly in areas of thin till that have steep slopes and irregular topography. Some postglacial units were mapped using 2005 orthophoto images.

\section{Assawompset Pond Quadrangle}

Map units were reproduced from Koteff (1964). Glacial stratified deposits include predominantly coarse-grained glaciofluvial and glaciodeltaic sediments grouped in meltwater sequence deposits (units $\mathrm{Qc}_{1}, \mathrm{Qc}_{2}, \mathrm{Qc}_{5}-\mathrm{Qc}_{7}, \mathrm{Qce}_{3-4}, \mathrm{Qcw}_{3-4}$ ) and noncorrelated deposits (units $\mathrm{Qc}$, Qsg) included in water-laid ice contact deposits of Koteff (1964). These deposits were graded to local glacial lakes in the Fall Brook and Squam Brook valleys, the Nemasket River lowland, and to glacial Lake Narragansett in the Taunton River lowland in the northwest corner of the map area. Stagnant-ice deposits include coarse-grained glaciofluvial and glaciodeltaic sediments, flowtill deposits and boulders, mapped as kame deposits (unit Qc) by Koteff (1964). Small moraine deposits composed of coarse gravel and sand are unit Qem 2 of Koteff (1964). Thick-till areas were delineated based on topographic analysis and subsurface data of Williams and Willey (1973). Additional areas of thick till may be expected beneath smooth slopes on the northerly sides of bedrock hills. Distribution of bedrock outcrops is from Koteff (1964). The shallow-bedrock unit is slightly modified from the 
ruled pattern area of bedrock exposures of Koteff (1964), which is defined as "areas of abundant exposures and thin surficial deposits". Some postglacial units were mapped using 2005 orthophoto images.

\section{Snipatuit Pond Quadrangle}

Thiesmeyer, L.R , and Goldthwait, R.P. (1940, unpublished field map); and Stone B.D., and Kincare, K.A., assisted by A. Lusk (2010, unpublished field map). Glacial stratified deposits include predominantly coarse-grained glaciofluvial and glaciodeltaic sediments that were graded to small glacial lakes in the Weweantic River and Sippican River valleys, and to glacial Lake Narragansett in the Taunton River lowland. Distribution of bedrock outcrops is from Williams and Willey (1973) and Lyons (1977). Additional areas of thick till may be expected, particularly beneath smooth slopes on the northerly sides of bedrock hills. Some postglacial units were mapped using 2005 orthophoto images.

\section{Wareham Quadrangle}

Goldthwait, R.P., and Thiesmeyer, L.R. (1940, unpublished field maps); Stone, B.D., and Kincare, K.A. (2010, unpublished field maps). Glacial stratified deposits include predominantly coarsegrained glaciofluvial and glaciodeltaic sediments mapped as part of the Wareham and King's Pond outwash plains and the collapsed sand and gravel sediments of the Hog Rock moraine (Mather and others 1942; Larson, 1982). Stagnant-ice deposits include coarse-grained glaciofluvial and glaciodeltaic sediments, flowtill deposits and boulders (Mather and others, 1942; Larson, 1982). Thick-till areas were delineated based on topographic analysis and subsurface data of Williams and Tasker (1974). Additional areas of thick till may be expected beneath smooth slopes on the northerly sides of bedrock hills. Some postglacial units were mapped using 2005 orthophoto images.

\section{Sagamore Quadrangle}

Map units were modified from Thiesmeyer (1940, unpublished field map) and Stone and Kincare (2010, unpublished field map). Glacial stratified deposits include predominantly coarse-grained glaciofluvial and glaciodeltaic sediments mapped as part of the Wareham outwash plain and the collapsed sand and gravel sediments of the Hog Rock moraine (Mather and others, 1942; Larson, 1982). Other parts of these deposits were graded to local glacial lakes in the southeastern and northeastern parts of the map area. Stagnant-ice deposits include coarse-grained glaciofluvial and glaciodeltaic sediments, flowtill deposits, and boulders. Moraine deposits are part of the Sandwich moraine of Thiesmeyer (1940, unpublished) in the southern part of the map area. Thick-till areas were delineated based on topographic analysis and subsurface data of Williams and Tasker (1974). Some postglacial units were mapped using 2005 orthophoto images.

\section{Bristol Quadrangle}

Map units were reproduced from Smith (1955). Glacial stratified deposits include predominantly coarse-grained glaciofluvial and glaciodeltaic sediments of outwash plain deposits (unit Qop) of Smith (1955), which grade to glacial Lake Narragansett deposits in the eastern Narragansett Bay lowland. Some postglacial units were mapped using 2005 orthophoto images. 


\section{Fall River Quadrangle}

Peper, J.D., assisted by D.A. Powars and M. Baginski (1982, unpublished field map). Distribution of bedrock outcrops is from Lyons (1977), Willey and others (1978), and Peper (1982, unpublished). Glacial stratified deposits include predominantly coarse-grained glaciofluvial and glaciodeltaic sediments graded to small glacial lakes in the Deerfield River, West Branch North River, and Mill Brook valleys. Thick-till areas were delineated based on topographic analysis. The shallow bedrock unit represents areas of abundant outcrop but is shown only where the bedrock mapper made structural measurements. Additional bedrock outcrops and shallow-bedrock areas are most likely present, particularly in areas of thin till with steep slopes and irregular topography Some postglacial units were mapped using 2005 orthophoto images.

\section{Fall River East Quadrangle}

Peper, J.D., assisted by D.A. Powars and M. Baginski (1982, unpublished field map). Distribution of bedrock outcrops is from Williams and Willey (1973), Lyons (1977), Willey and others (1978), and Peper (1982, unpublished). Glacial stratified deposits include predominantly coarse-grained glaciofluvial and glaciodeltaic sediments graded to small glacial lakes in the Deerfield River, West Branch North River, and Mill Brook valleys. Thick-till areas were delineated based on topographic analysis. The shallow bedrock unit represents areas of abundant outcrop but is shown only where the bedrock mapper made structural measurements. Additional bedrock outcrops and shallowbedrock areas are most likely present, particularly in areas of thin till with steep slopes and irregular topography. Some postglacial units were mapped using 2005 orthophoto images.

\section{New Bedford North Quadrangle}

Peper, J.D., assisted by D.A. Powars and J.C. Haley (1982, unpublished field map). Glacial stratified deposits include predominantly coarse-grained glaciofluvial and glaciodeltaic sediments graded to glacial Lake Narragansett in the lower Acushnet River valley and small glacial lakes in the Paskamanset River and upland Acushnet Cedar Swamp valleys. Thick-till areas were delineated based on topographic analysis and subsurface data of Williams and Tasker (1978). Distribution of bedrock outcrops is from Williams and Tasker (1978) and Peper (1982, unpublished). The shallowbedrock unit represents areas of small scattered bedrock outcrops. Additional bedrock outcrops and shallow-bedrock areas are most likely present, particularly in areas of thin till with steep slopes and irregular topography. Some postglacial units were mapped using 2005 orthophoto images.

\section{Marion Quadrangle}

Thiesmeyer, L.R , and Goldthwait, R.P. (1940, unpublished field map); Peper, J.D., and Stone, B.D. (1982, unpublished field map). Glacial stratified deposits include predominantly coarsegrained glaciofluvial and glaciodeltaic sediments graded to glacial Lake Narragansett in the Nasketucket River, Mattapoisett River, and coastal valley. Thick-till areas were delineated based on topographic analysis and subsurface data of Williams and Tasker (1978). Distribution of bedrock outcrops is from Williams and Tasker (1978) and Peper and Stone (1982, unpublished). Some postglacial units were mapped using 2005 orthophoto images. 


\section{Onset Quadrangle}

Thiesmeyer, L.R , and Goldthwait, R.P. (1940, unpublished field map); Peper, J.D., and Stone, B.D. (1982, unpublished field map). Glacial stratified deposits include predominantly coarsegrained glaciofluvial and glaciodeltaic sediments graded to glacial Lake Narragansett in the coastal valley; these deposits were mapped as part of the Wareham outwash plain and the collapsed sand and gravel sediments of the Hog Rock moraine (Mather and others, 1942; Larson, 1982). Other parts of these deposits were graded to local glacial lakes in the southeastern and northeastern parts of the map area. Stagnant-ice deposits include coarse-grained glaciofluvial and glaciodeltaic sediments, flowtill deposits, and boulders. Moraine deposits are part of the Sandwich moraine (Theismeyer, 1940, unpublished) in the southern part of the map area. Thick-till areas were delineated based on topographic analysis and subsurface data of Williams and Tasker (1974). Some postglacial units were mapped using 2005 orthophoto images.

\section{Tiverton Quadrangle}

Map units were modified from Stone (1982, unpublished field map). Glacial stratified deposits include predominantly coarse-grained glaciofluvial and glaciodeltaic sediments graded to a local glacial lake in the Stony Brook (Sawdy Pond) valley. Distribution of bedrock outcrops is from Willey and others (1978) and Stone (1982, unpublished). The shallow-bedrock unit represents areas of small scattered bedrock outcrops. Areas of thick till may be expected beneath smooth slopes on the northerly sides of bedrock hills.

\section{Westport Quadrangle}

Peper, J.D., and Stone, B.D., assisted by D.A. Powars and M. Baginski (1982, unpublished field map); Willey and others (1978). Glacial stratified deposits include predominantly coarse-grained glaciofluvial and glaciodeltaic sediments graded to small glacial lakes in the Deerfield River, West Branch North River, and Mill Brook valleys. Thick-till areas were delineated based on topographic analysis. The shallow bedrock unit represents areas of abundant outcrop but is shown only where the bedrock mapper made structural measurements. Additional bedrock outcrops and shallowbedrock areas are most likely present, particularly in areas of thin till with steep slopes and irregular topography. Some postglacial units were mapped using 2005 orthophoto images.

\section{New Bedford South Quadrangle}

Peper, J.D., and Stone, B.D., assisted by D.A. Powars and J.C. Haley (1982, unpublished field map). Glacial stratified deposits include predominantly coarse-grained glaciofluvial and glaciodeltaic sediments graded to glacial Lake Narragansett in the Slocums River and Little River valleys and small glacial lakes in the Paskamanset River valley. Thick-till areas were delineated based on topographic analysis and subsurface data of Williams and Tasker (1978). Distribution of bedrock outcrops is from Williams and Tasker (1978) and Peper and Stone (1982 unpublished). The shallow-bedrock unit represents areas of small scattered bedrock outcrops. Thick-till areas were delineated based on topographic analysis. The shallow bedrock unit represents areas of abundant outcrop but is shown only where the bedrock mapper made structural measurements. Additional bedrock outcrops and shallow-bedrock areas are most likely present, particularly in areas of thin till with steep slopes and irregular topography. Some postglacial units were mapped using 2005 orthophoto images. 


\section{Sconticut Neck Quadrangle}

Peper J.D., assisted by J. Buchanan (1982, unpublished field map). Distribution of bedrock outcrops is from Williams and Tasker (1978) and Peper (1982, unpublished). Thick-till areas were delineated based on topographic analysis. Some postglacial units were mapped using 2005 orthophoto images. 